\title{
Exploring the issue of content, pedagogical and technological knowledge among preschool teachers
}

\author{
Jain Chee ${ }^{1, *}$, M.N. Mariani ${ }^{1}$, Abdul Jalil Othman ${ }^{1}$, M.R. Nor Mashitah ${ }^{2}$ \\ ${ }^{1}$ Faculty of Education, University of Malaya, 50603 Kuala Lumpur, Malaysia \\ ${ }^{2}$ Department of Early Childhood and Education, Faculty of Education and Human Development, Sultan Idris Education \\ University, Perak, Malaysia
}

\section{A R T I C L E IN F O}

\section{Article history:}

Received 2 November 2016

Received in revised form

21 January 2017

Accepted 25 January 2017

Keywords:

Preschool teacher

Content knowledge

Pedagogical knowledge

Technological knowledge

\begin{abstract}
A B S T R A C T
The study aimed to explore the Technological Pedagogical Content Knowledge (TPACK) of preschool teachers towards preparing pupils to Year One. The main aspect being explored is the Content Knowledge (CK), Pedagogical Knowledge (PK) and Technological Knowledge (TK) by investigating understanding, transforming and classroom teaching practice in preschool. The design of this study was a case study with four preschool teachers was selected as the research participants. Data were collected in the form of interviews, teaching observation and document analysis in duration of six months. The main interview was held six times, pre and post-teaching interviews held during the teaching processes and the critical incident interviews held once. While, teaching observation was held five times. All interviews were audio and video recorded while field notes were used to record teaching observations. Analysis of the content of the document based on the purpose of the study. Data was analyzed based on previous research. Validity and reliability based on triangulation method, pilot study, research participants' validation, Cohen Kappa Index Scale and the duration of the study. The study found, research participants do not have extensive knowledge and understanding of curriculum content and technology of teaching. However, research participants have very good knowledge and understanding of pedagogy. While, the teachers emphasized on teaching planning and preparation of lesson plans while the implementation of teaching more focused on skills in reading, writing and mathematics to prepare pupils to Year One, compare to teaching activities to produce balance humanism in terms of physically, mentally, emotionally, spiritual and personality.
\end{abstract}

(C) 2017 The Authors. Published by IASE. This is an open access article under the CC BY-NC-ND license (http://creativecommons.org/licenses/by-nc-nd/4.0/).

\section{Introduction}

Technological Pedagogical Content Knowledge (TPACK) by Mishra and Koehler (2006) attempts to identify the nature of knowledge required by teachers for technology integration in their teaching, while addressing the complex, multifaceted and situated nature of teacher knowledge. The TPACK framework extends Shulman's idea of Pedagogical Content Knowledge. The heart of the TPACK framework is the complex interplay of three primary forms of knowledge: Content (CK), Pedagogy (PK), and Technology (TK). The TPACK approach goes

\footnotetext{
* Corresponding Author.

Email Address: jainchee@yahoo.com (J. Chee)

https://doi.org/10.21833/ijaas.2017.03.020

2313-626X/C) 2017 The Authors. Published by IASE.

This is an open access article under the CC BY-NC-ND license

(http://creativecommons.org/licenses/by-nc-nd/4.0/)
}

beyond seeing these three knowledge bases in isolation. The TPACK framework goes further by emphasizing the kinds of knowledge that lie at the intersections between three primary forms: Pedagogical Content Knowledge (PCK), Technological Content Knowledge (TCK), Technological Pedagogical Knowledge (TPK) and Technological Pedagogical Content Knowledge (TPACK) as shown Fig. 1.

Effective technology integration for pedagogy around specific subject matter requires developing sensitivity to the dynamic, transactional relationship between these components of knowledge situated in unique contexts. Individual teachers, grade-level, school-specific factors, demographics, culture and other factors ensure that every situation is unique and no single combination of content, technology and pedagogy will apply for every teacher, every course or every view of teaching. 


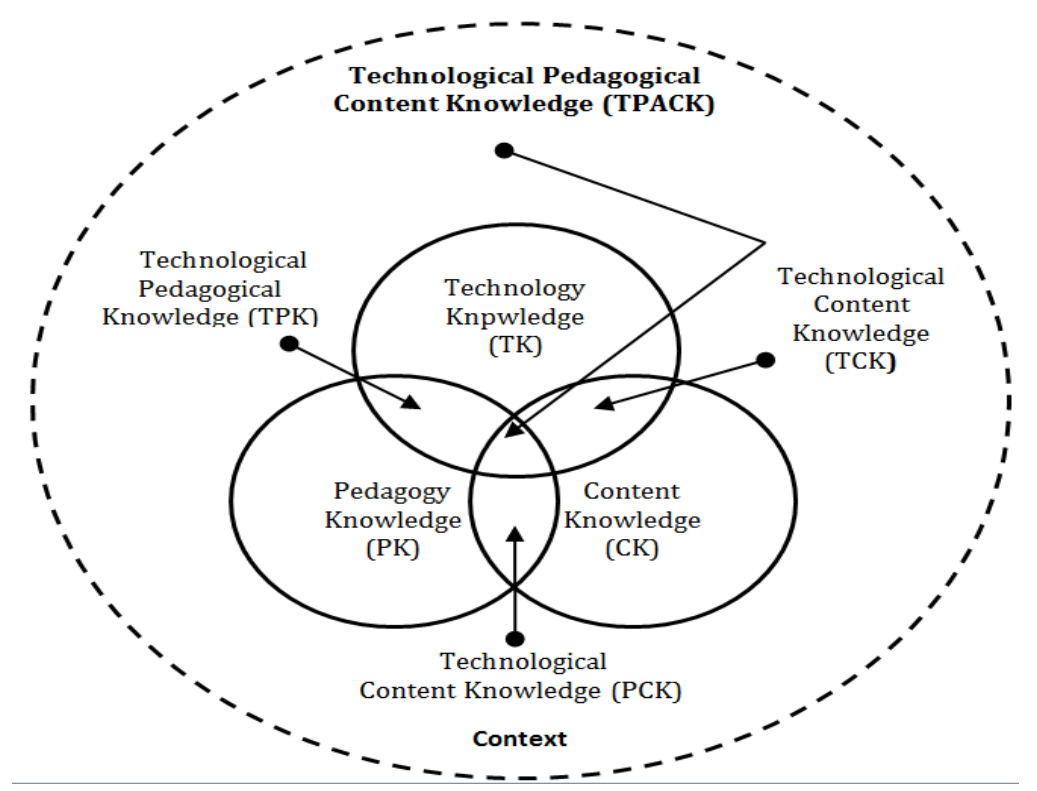

Fig. 1: Technological pedagogical content knowledge

\subsection{Content knowledge}

According to Shulman (1986), content knowledge is an understanding of the subject as a discipline. Shulman (1992) believes content knowledge is a knowledge structure which covers the theory, concepts and principles of a particular discipline. Therefore, to teach a subject, teachers need to have a good content knowledge (Hasniza, 2014; Usiskin, 2002). However, it is difficult to measure and determine the content knowledge required teachers of subjects talk (McIntyre, 1990; Siti, 2012; Shulman, 1986). Therefore, as long as there are problems in teaching, teachers need to gain as much knowledge on a continuous basis from a variety of sources, including knowledge related to teaching and learning processes.

Studies prove content knowledge affect the way teachers plan and teach a subject (Siti, 2012). Study of Shulman (1992) showed mastery of content knowledge by teachers teaching plans and actions influence in the classroom. The findings also indicated through the study of Siti (2012). This means the actions and attitudes of teachers in the process of teaching in the classroom teacher's thought process is influenced by including content knowledge (Grossman, 1990; McDiarmid et al., 1989; Siti, 2012).

\subsection{Pedagogical knowledge}

Knowledge of pedagogy refers to the principles in the planning, management and operation of class strategy (Shulman, 1992; 1987). In other words, ways of teaching teachers influenced by knowledge of pedagogy in particular approaches and techniques used for teaching. The weaknesses of teacher pedagogy related to their understanding about it, about what is taught and how to teach (Hasniza, 2014; Siti, 2012).
Kreber and Cranton (2000) said pedagogical knowledge is the knowledge about how a person learns and how learning can be facilitated. Pedagogical knowledge including about learning styles, cognitive styles and cognitive processes in learning. Pedagogical knowledge focus on how to teach the subject matter, how to help students master learning how to use critical thinking and independent learning.

Mishra and Koehler (2006) and Bonner (2001) believed pedagogical knowledge is the beliefs and perceptions that affect the implementation of the curriculum and reflect teaching strategies used by teachers to implement teaching. Teachers who do not have a pedagogical knowledge may not achieve satisfaction in his career because of the satisfaction in the teaching depends on pedagogical knowledge (Schempp et al., 1998).

Therefore, teachers are more comfortable and excited about teaching students they are experts because they can adjust their pedagogical knowledge with various abilities of students, students' interest in subjects related or have a relationship with the teacher. According to Mishra and Koehler (2006), a subject which is not desirable as a way of teaching less attractive and does not mean anything.

\subsection{Technological knowledge}

Technological Knowledge refers to knowledge about the methods of applying or integrating technology namely the equipment and resources available around the workplace (Mishra and Koehler, 2006). Integrating technology into teaching includes all equipment and technology resources in the classroom. According to Mishra and Koehler (2006), integrating technology in teaching, including an understanding of information technology is used productively in teaching and can help or hinder the goals to be achieved in teaching. Integrating technology in teaching also means adapting to 
changes in technology including the planning of teaching and delivering teaching (Siti, 2012; Mishra and Koehler, 2006).

According to Bates (2000), the rapid development of technology of the 21st century has revealed a generation now to new innovations in technology. Therefore, Bates (2000) saied the need to do something faster, change to meet the needs of the community through the effects of the use of new technology become main factors through teaching in educational institutions now changes. According to him, technology plays an important role in ensuring the effectiveness of administrative activities and teaching in school.

The integration of technology in teaching increase cooperative learning, improving curriculum integration, diversification strategies and learning styles, improve communication teachers, community relations and learning globally (Koehler and Mishra, 2009; Whitehead et al., 2013).

In addition, the integration of technology in teaching and support the goals of education apply to a transformation in the country. Planning to use technology in education is not only focused on the use of computers and software, but includes learning more meaningful, meet the needs of professional development and support and flexible to adapt to changing circumstances (Rozaiman et al., 2016; Siti, 2012).

\subsection{Problem statement}

According to School Inspectorate and Quality Assurance (SIQA), the Ministry of Education through the examination of teaching at pre-school classes in 2012 and 2013, there were among preschool teacher who examined a lack of understanding about the content of the preschool curriculum. According to SIQA, this affects the inability of teachers to give a clear explanation of a skill and cannot convey the teaching significantly, especially in its information campaign on a concept of the skills taught.

The second issue through the study is less understanding of the need and importance of pedagogical knowledge according to the needs of preschool education as proposed National Standard Preschool Curriculum (NSPC). According to MOE (2012) in which observed among preschool teacher found, they lack teaching approach as proposed curriculum. According MOE (2012, 2013), monitored the implementation of the teaching-centered teacher with student participation in the learning activities are very limited. This means the teacher does not to apply the education preschool pedagogy. These issue cause problems to pupils in preschool because in the context of preschool in Malaysia, pupils in aged 4 to 6 years. Piaget (1952) said children aged 2 to 7 years old at the stage of pre-operational phase in cognitive development. According to Piaget (1952) on stage phases preoperative, children learn to use the scheme which is based on the use of language and forms of representation of the other symbols to solve problems or understand a thing.
The third issue of this study is technological knowledge in the implementation of teaching preschool. Although technology in teaching has been introduced (Kelly, 2007; Lim, 2007), there is still a lack of knowledge among teachers about technology and not willing to use technology in teaching (Siti, 2012). Sandra et al. (2013) identified a number of factors caused the teachers are reluctant to use technology in teaching, including less disintegration of the meaning of 'technology', there are weaknesses in the design of software, skepticism about the effectiveness of computers in improving learning outcomes, less administrative support, time and effort required to learn the technology and how to use technology to teach and fear of losing their power in the classroom for teaching technology integrated usually centered learning (Hannafin, 1999).

\subsection{Objective of the study}

Specifically, the objective of this study was to explore the knowledge and understanding of PK, PP, PT and how through understanding the teachers teaching in preschool classes. The following are the objectives of this study:

\section{To explore content knowledge of preschool teacher. \\ 2. To explore Pedagogical knowledge of preschool teachers. \\ 3. To explore technological knowledge of preschool teachers.}

\section{Methodology}

This is a qualitative case study design or multiple cases, study (Yin, 2003) with four preschool teachers chosen as research participants. The data collected through interviews protocol, teaching observation protocol and document analyzing for six months. The main interview and critical incidents interview was done to inquire the background of the research participants and their knowledge of the National Standard Preschool Curriculum (NSPC) of Malaysia, while pre and post-teaching interviews were held to obtain more information regarding a lesson through teaching observation (MOE, 2010).

The main interview was held six times, pre and post-teaching interviews held during the teaching processes and the critical incident interviews held once. Meanwhile, teaching observation was held five times. The teaching observation of lesson was done by video recordings and field notes to explored participant's knowledge of teaching preparation and teaching skills in preschool classroom and analysis of the content of the document based on the purpose of the study. Data was analyzed based on Miles and Huberman (1994). Validity and reliability based on triangulation method, pilot study, research participants' validation, Cohen Kappa Index Scale and the duration of the study. 


\section{Results and discussion}

The results and discussion covering the objective of the study 1,2 and 3.

\subsection{Results}

Knowledge and understanding of the content, pedagogy and technology are shown as keyword: RP = Research Participants; $\mathrm{Y}=$ Has knowledge and understanding; $\mathrm{Ne}=$ Not enough; $\mathrm{N}=$ Not have.

\subsubsection{First objective}

The first objective is to explore content knowledge of preschool teacher. The study found that all four research participants do not have a full content knowledge refers to the National Standard Preschool Curriculum (NSPC) based on their understanding of the conceptual framework NSPC, content and learning outcomes as shown by response interview and observation teaching. However, the study found that all research participants perform teaching and learning NSPC guided except PK1. They also find managing curricular activities based on the experience of using the previous curriculum; have basic knowledge about theory and the need to operate the preschool class. Summary of findings the content knowledge of research participants shown as Table 1.

\subsubsection{Second objective}

The second objective is to explore pedagogical knowledge of preschool teachers. The study found that all four research participants have strong knowledge and understanding of specific of pedagogical knowledge for preschool education that includes approaches, techniques and skills to deliver teaching. This is shown through response interview, observation and content analysis document Daily Lesson Plan (DLP) research participants. However, the study found all research participants did not implement technology-based learning because the technology equipment has been damaged. However, all research participants were found to implement teaching and learning using other teaching aids supplied by Ministry of Education or provided itselfaligned with the curriculum, teaching approaches and techniques. The study also found pedagogical knowledge of all research participants based on their teaching experience in preschool for more than 10 years. Summary of findings the pedagogical knowledge of research participants shown as Table 2.

Table 1: Summary of content knowledge

\begin{tabular}{|c|c|c|c|c|c|c|}
\hline \multirow[t]{2}{*}{ Constructs } & \multirow[t]{2}{*}{ Theme } & \multirow[t]{2}{*}{ Sub-Theme } & \multicolumn{4}{|c|}{$\begin{array}{l}\text { Knowledge and } \\
\text { Understanding }\end{array}$} \\
\hline & & & RP1 & RP2 & RP3 & RP4 \\
\hline \multirow{10}{*}{$\begin{array}{l}\text { Content } \\
\text { Knowledge }\end{array}$} & \multirow{2}{*}{ Preschool Conceptual } & Preschool Conceptual Knowledge & $\mathrm{N}$ & $\mathrm{Ne}$ & $\mathrm{Ne}$ & $\mathrm{N}$ \\
\hline & & Early Childhood Theory Knowledge & $\mathrm{N}$ & $\mathrm{N}$ & $\mathrm{N}$ & $\mathrm{N}$ \\
\hline & \multirow{2}{*}{$\begin{array}{c}\text { Conceptual Framework } \\
\text { NSPC }\end{array}$} & $\begin{array}{l}\text { Conceptual Framework NSPC and Understanding of } \\
\text { Teaching Time }\end{array}$ & $\mathrm{N}$ & $\mathrm{Ne}$ & $\mathrm{Ne}$ & $\mathrm{N}$ \\
\hline & & Learning Based on Modul Teras Asas and Modul Bertema & $\mathrm{N}$ & $\mathrm{Ne}$ & $\mathrm{Ne}$ & $\mathrm{Ne}$ \\
\hline & \multirow{2}{*}{ Content } & Content Knowledge of NSPC & $\mathrm{N}$ & $\mathrm{Ne}$ & $\mathrm{Ne}$ & $\mathrm{Ne}$ \\
\hline & & Selection of Content in Teaching and Learning & $\mathrm{Ne}$ & Y & Y & $\mathrm{N}$ \\
\hline & \multirow{4}{*}{ Outcomes } & $\begin{array}{l}\text { Requirements of Activities Reading and writing in Bahasa } \\
\text { Malaysia }\end{array}$ & Y & Y & Y & Y \\
\hline & & Early Math Activities Requirements & Y & Y & Y & Y \\
\hline & & Requirements of Knowledge and Value of Learning & & & & $\mathrm{N}$ \\
\hline & & $\begin{array}{l}\text { Activities } \\
\text { oants } \mathrm{Y}=\text { Has knowledge and understanding: } \mathrm{Ne}=\text { Not enough } \mathrm{N}\end{array}$ & $\frac{\mathrm{N}}{\text { ave }}$ & $\mathrm{N}$ & $\mathrm{N}$ & $\mathrm{N}$ \\
\hline
\end{tabular}

\subsubsection{Third objective}

The third objective is to explore technological knowledge of preschool teachers. The study found that all four research participants' do not have fully of technological knowledge related to the integration of technology in teaching and how to implement teaching using technology. The study found research participants' less exposure and training on the matter, in addition to technological equipment supplied was damaged and power failure. However, all research participants ready to approach and integrate technology in teaching if they have technological knowledge, preschool classes are provided with equipment and adequate technology resources, as well as basic supplies such as electricity supplied properly. Summary of the findings of the technological knowledge shown as Table 3.

\subsection{Discussion}

Content knowledge, pedagogy knowledge and technology knowledge are discussed as follows.

\subsubsection{Content knowledge}

Overall, the study found that understanding and knowledge of the content knowledge of research participants is not completely. However, study participants have an awareness of the importance and the need to have an understanding and knowledge and to master the content knowledge. 
This is demonstrated through interviews and observation.

Table 2: Summary of pedagogical knowledge

\begin{tabular}{|c|c|c|c|c|c|c|}
\hline \multirow{2}{*}{ Constructs } & \multirow[t]{2}{*}{ Theme } & \multirow[t]{2}{*}{ Sub-Theme } & \multicolumn{4}{|c|}{$\begin{array}{l}\text { Knowledge and } \\
\text { Understanding }\end{array}$} \\
\hline & & & RP1 & RP2 & RP3 & RP4 \\
\hline \multirow{8}{*}{$\begin{array}{l}\text { Pedagogical } \\
\text { Knowledge }\end{array}$} & \multirow{2}{*}{ Teaching Approach } & Teaching Approach in Context of Preschool Education & $\mathrm{Y}$ & $\mathrm{Y}$ & $\mathrm{Y}$ & $\mathrm{Y}$ \\
\hline & & Selecting and Determine the Approach Teaching & Y & Y & $\mathrm{Y}$ & $\mathrm{Y}$ \\
\hline & \multirow[t]{2}{*}{ Teaching Techniques } & $\begin{array}{l}\text { Teaching Techniques in Context of Preschool } \\
\text { Education }\end{array}$ & $\mathrm{Y}$ & $\mathrm{Y}$ & Y & $\mathrm{Y}$ \\
\hline & & Selecting and Determine Teaching Techniques & $\mathrm{Y}$ & Y & Y & Y \\
\hline & \multirow{2}{*}{ Teaching Aids } & Selection of Teaching Aids & Y & Y & Y & $\mathrm{Y}$ \\
\hline & & Managing and Implementation of Teaching Aid & $\mathrm{Ne}$ & Y & Y & Y \\
\hline & Classroom & Managing of preschool Children & $\mathrm{Y}$ & $\mathrm{Y}$ & Y & Y \\
\hline & Management & Time Management of Teaching and Learning & $\mathrm{Ne}$ & $\mathrm{Ne}$ & $\mathrm{Ne}$ & $\mathrm{Y}$ \\
\hline
\end{tabular}

Table 3: Summary of technological knowledge

\begin{tabular}{|c|c|c|c|c|c|c|}
\hline \multirow[t]{4}{*}{ Constructs } & \multirow[t]{2}{*}{ Theme } & \multirow[t]{2}{*}{ Sub-Theme } & \multicolumn{4}{|c|}{$\begin{array}{l}\text { Knowledge and } \\
\text { Understanding }\end{array}$} \\
\hline & & & RP1 & $\mathrm{RP} 2$ & RP3 & RP4 \\
\hline & Technological Annroach & Technological Approach in Teaching & $\mathrm{N}$ & $\mathrm{Ne}$ & $\mathrm{Ne}$ & $\mathrm{N}$ \\
\hline & lecnnological Approacn & Applying of Technological Approach in Teaching & $\mathrm{N}$ & $\mathrm{Ne}$ & $\mathrm{Ne}$ & $\mathrm{N}$ \\
\hline \multirow{6}{*}{$\begin{array}{l}\text { Technological } \\
\text { Knowledge }\end{array}$} & Willingness Integration of & $\begin{array}{l}\text { Understanding of the integration of technology in } \\
\text { teaching }\end{array}$ & $\mathrm{Ne}$ & $\mathrm{Ne}$ & $\mathrm{Ne}$ & $\mathrm{N}$ \\
\hline & & $\begin{array}{l}\text { The availability of an integrated technology in } \\
\text { teaching }\end{array}$ & $\mathrm{Y}$ & $\mathrm{Y}$ & $\mathrm{Y}$ & $\mathrm{Y}$ \\
\hline & Suitability of materials & Learning Materials Integration Technology & $\mathrm{N}$ & $\mathrm{N}$ & $\mathrm{N}$ & $\mathrm{N}$ \\
\hline & integrity Technology & Suitability of Materials Integration Technology & $\mathrm{N}$ & $\mathrm{N}$ & $\mathrm{N}$ & $\mathrm{N}$ \\
\hline & $\begin{array}{l}\text { An integrated Technology } \\
\text { infrastructure }\end{array}$ & $\begin{array}{l}\text { School for The Integration of Technology } \\
\text { Infrastructure }\end{array}$ & $\mathrm{N}$ & $\mathrm{N}$ & $\mathrm{N}$ & $\mathrm{N}$ \\
\hline & & Facility technology in Preschool Classes for lessons & $\mathrm{N}$ & $\mathrm{N}$ & $\mathrm{N}$ & $\mathrm{N}$ \\
\hline
\end{tabular}

This study supports Hasniza (2014), Smith (2010), and Shulman (1986) who noted the importance of understanding and knowledge about specific subjects. This study also confirms the fact that the importance of knowledge about the concepts of a subject to perform teaching effectively (Hasniza, 2014; Usiskin, 2002; Shulman, 1986).

The study also found that all research participants teaching focused on aspects cognitive and not in line with NSPC of providing students into Year One and human well-balanced in terms of physical, emotional, spiritual and character. The findings of this study contrary to Siti (2012), Anderson and Pavan (1998) who said identity formation of students should be the primary goal of education in schools especially for the generation that is balanced in terms of intellect and personality to improve human relations. This finding supports the studies by Siti (2012) and Smith (2010) who found that teachers have low understanding and knowledge of the contents have had to carry out the teaching of these subjects.

\subsubsection{Pedagogical knowledge}

The study found all research participants have an understanding on the approach and teaching techniques proposed by NSPC. However, teaching of observation found, research participants less to implement the proposed approach. They tend to approach teaching teacher-centered teaching methods and give instructions such as using approaches and techniques to teach students to memorize skills reading, writing and mathematics. Thus, this finding is not consistent with Kreber and Cranton (2000) which sets out specific techniques for preschool children must base on age, development, talent, ability and interest to help children think in critical and at the same time provides to Year One and balanced human.

The findings showed a classroom management in teaching passable, especially in terms of disciplinary control. Such a situation is as intended NSPC. The findings of this study in line with the Siti (2012). Knowledge of classroom management should know how to motivate students, moving collaboration among students, helping students overcome learning difficulties, help students think in critical and way to get meaningful feedback.

\subsubsection{Technological knowledge}

The findings show teachers need to be more exposed to the technological knowledge, so that they can understand and have knowledge of technology to their applied integration of technology in teaching. This is in line with the NSPC and Plan of Development of Malaysian Education 2013-2025. In 
addition, in accordance with the Mishra and Koehler (2006) said knowledge technology is about a specific method to work with technology, whether low or high technology and technology resources around the workplace. The study also found that research participants ready to integrate technology in teaching if they receive training about knowledge technology and provided with adequate technological equipment such as finding by Sandra et al. (2013).

\section{Conclusion}

Epistemologi or theory of knowledge focuses on what we know and how we know. It is a branch of philosophy that considered the nature and scope of knowledge and basic assumptions and general reliability of knowledge claims. Study proves the need for teachers have content knowledge, pedagogical knowledge and technological knowledge to enable them to become effective teachers. Knowledge and understanding of content knowledge, pedagogical knowledge and technological knowledge used to explain teachers' understanding about what makes learning particular headings happy or difficult, concepts, pre-concept and misconceptions held by students. Knowledge and understanding of content knowledge, pedagogical knowledge and technological knowledge also clearly showed that the effectiveness of teaching and learning is highly dependent on the ability of teachers to see and put real life critically in the classroom to solve problems as well as issues related too educational, moral, social, and religious, etc. However, exposure and training on the content knowledge, pedagogical knowledge and technological knowledge continued to be held, this can add to the value of the professional knowledge of teachers.

However, the integration of technology is the latest approach in teaching and learning in preschool classes. Integration in teaching can change the role of the teacher from instructor to facilitator and exposition based teaching methods can be changed to teaching that allows students to explore either individually or in small groups. Therefore, the integration of individual technologies provides learning opportunities for students to receive instruction and receiving instruction in line with current developments. However, the need for the integration of technology in teaching should be given priority. The Ministry of Education should provide the infrastructure associated with the technology to enable and facilitate more teachers implement technology-based instruction. Support personnel who can carry out maintenance and repair computer must also be placed in schools that teachers have the skills of maintenance and repair computers are not charged with the task of repair and maintenance of computers.

The culture of the school should be transformed from something by memory to a knowledgeable, minded, creative and loving with the latest technology. Educators also need to be open and positive changes in the education received. Cooperation from all parties will drive the country's education system towards world-class excellence, particularly in preschool education.

\section{References}

Anderson RH and Pavan BN (1998). Nongradedness: Helping it to happen. Technomic Publishing, Pennsylvania, USA.

Bates AW (2000). Managing technological change: Strategies for college and university leaders. Jossey-Bass Inc. Publishers, San Francisco, USA.

Bonner PS (2001). The influence of secondary science teachers' pedagogical content knowledge, educational beliefs and perceptions of the curriculum on implementation and science reform. Ph.D. Thesis, University of Connecticut, USA.

Grossman PL (1990). The making of a teacher: Teacher knowledge and teacher education. Teachers College Press, New York, USA.

Hannafin RD (1999). Can teachers' attitudes about learning be changed?. Journal of Computing in Teacher Education, 15(2): 7-13.

Hasniza N (2014). Pre-service teachers' TPACK and experience of ICT integration in schools in Malaysia and New Zealand. Ph.D. Dissertation, University of Canterbury, New Zealand.

Kelly C (2007). Student's perceptions of effective clinical teaching revisited. Nurse Education Today, 27(8): 885-892.

Koehler MJ and Mishra P (2009). What is technological pedagogical content knowledge?. Contemporary Issues in Technology and Teacher Education, 9(1): 60-70.

Kreber C and Cranton PA (2000). Exploring the scholarship of teaching. Journal of Higher Education, 7(14): 476-495.

Lim CP (2007). Effective integration of ICT in Singapore schools: Pedagogical and policy implications. Educational Technology Research and Development, 55(1): 83-116.

McDiarmid GW, Ball DL and Anderson CA (1989). Why saying one chapter ahead doesn't really work: Subject-specific pedagogy. Reynolds DM (Ed.), Knowledge Base for the beginning teacher: 1-28. Pergamon, Oxford, UK.

McIntyre D (1990). Ideas and principles guiding the internship scheme. In: Benton P (Ed.), The Oxford Internship Scheme: Integration and Partnership in Initial Teacher Education: 1733. Calouste Gulbenskin Foundation, London, England.

Miles HB and Huberman AM (1994). Qualitative data analysis: An expanded sourcebook. Sage Publications, California, USA.

Mishra P and Koehler MJ (2006). Technological pedagogical content knowledge: A framework for teacher knowledge. Teachers College Record, 108(6): 1017-1054.

MOE (2010). National standard preschool curriculum. Department of Curriculum Developing. Ministry of Education, Kuala Lumpur, Malaysia.

MOE (2012). School Inspectorate and Quality Assurance (SIQA) of National Preschool Teaching Report. Ministry of Education, Kuala Lumpur, Malaysia.

MOE (2013). School Inspectorate and Quality Assurance (SIQA) of National Preschool Teaching Report. Ministry of Education, Kuala Lumpur, Malaysia.

Piaget J (1952). The origins of intellect. International University Press, New York, USA.

Rozaiman M, Zamri M, Noor IMT, and Haron AR (2016). Pengetahuan teknologikal pedagogikal kandungan kesusasteraan melayu: peranan guru sastera dalam SPN 21 [Technological pedagogical content knowledge in Malay literature: The roles of Malay literature teachers in SPN 21]. 
Jurnal Pendidikan Bahasa Melayu [Malay Language Journal Education], 1(2): 85-98.

Sandra R, Abu BN and Norlidah A (2013). Penggunaan ICT merentas Kurikulum Standard Prasekolah Kebangsaan (KSPK): Tinjauan di prasekolah Kementerian Pelajaran Malaysia. Jurnal Kurikulum and Pengajaran Asia Pasifik, 1(4): 12-20.

Schempp P, Manross D and Tan S (1998). Subject expertise and teachers' knowledge. Journal of Teaching in Physical Education, 17(3): 342-356.

Shulman LS (1986). Those who understand teach: Knowledge growth in teaching. Educational Researcher, 15(2): 4-14.

Shulman LS (1987). Knowledge and teaching: Foundations of the new reform. Harvard Educational Review, 57(1): 1-22.

Shulman LS (1992). Ways of seeing, ways of knowing ways of teaching, ways of learning about teaching. Journal of Curriculum Studies, 23(5): 393-396.
Siti HN (2012). Kajian kes terhadap amalan pengetahuan teknologi pedagogi dan kandungan (PTPK) guru fizik Johor Bahru. Ph.D. Dissertation, Universiti Teknologi Malaysia, Johor, Malaysia.

Smith C (2010). Mathematics in early childhood: An investigation of mathematics skill in preschool and kindergarten students. Ph.D. Thesis, Alfred University, New York, USA.

Usiskin Z (2002). Teachers need a special type of content knowledge. ENC Focus, 9(3): 14-15.

Whitehead BM, Jensen DFN and Boschee F (2013). Planning for technology: A guide for school administrators, technology coordinators, and curriculum leaders. Corwin Press, California, USA.

Yin RK (2003). Case study research: Design and methods. SAGE Publications, California, USA. 